election to a fellowship of the Royal Society placed 8 hallmark on the value of his contributions to the field of science in which he specialized.

Prof. Horton went to London in 1914. There, in addition to his teaching and research work, he soon entered into the inner circles of university administration, culminating in 1939 with his election as vice-chancellor. He continued to hold this high and arduous office throughout the War. To quote the words used by the principal of the University in his latest report: "No period of its history was more fraught with danger for the University than these six years, danger not only of physical destruction but of spiritual disintegration. Under the emergency measures which were taken to carry on tr: $\theta$ work of the University, the Vice-Chancellor was entrusted with wide powers. They were used with the utmost discretion and judgment. Professor Horton enjoyed none of the pomp and pageantry which fall to the lot of the Vice-Chancellor in normal times, but he must surely feel that the widespread and sincere tributes paid to his exceptional services afford some measure of compensation." The Senate, realizing that his term of office as a faculty representative was drawing to a close, paid tribute to the debt which it owed to his services by electing him as one of its co-opted members.

\section{National Institute of Sciences of India : Elections}

THE following have been elected ordinary fellows of the National Institute of Sciences of India : Mr. S. Basu, deputy director general (forecasting), Poona, distinguished for his work in weather forecasting; Dr. U. P. Basu, chief chemist, Bengal Immunity Co., Ltd., Calcutta, distinguished for his work in chemotherapy; Mr. J. Coates, senior geologist, Burmah Oil Co., Ltd., Digboi, distinguished for his work in geology; Dr. G. Krishnamurti, assistant director, Department of Chemotherapy, Haffkine Institute, Bombay, distinguished for his work on Indian medicinal plants ; Dr. B. S. Kadam, Central Tobaceo Research Station, Guntur, dis. tinguished for his work in genetics and plant breeding ; Prof. D. D. Kosambi, professor of mathematics, Tata Institute of Fundamental Research, Bombay, distinguished for his work in path geometry and statistics ; Mr. V. Khanolkar, director of laboratories, Tata Memorial Hospital, Bombay, distinguished for his work in human pathology; Dr. D. R. Malhotra, B.B. and C.I. Railway, Ajmer, distinguished for his work in metallurgical chemistry; Dr. B. Mundkur, mycologist, Imperial Agricultural Research Institute, New Delhi, distinguished for his work in systematic mycology ; Dr. B. Narayana, professor of physiology, Prince of Wales Medical College, Patna, distimguished for his work in physiology ; Dr. B. P. Pal, economic botanist, Imperial Agricultural Research Institute, New Delhi, distinguished for his work in genetics and plant breeding; Dr. V. G. Panse, statistician, Institute of Plant Industry, Indore, distinguished for his work on the application of statistical methods of plant breeding; Dr. P. B. Sarkar, senior research chemist, Indian Central Jute Committee, Calcutta, distinguished for his work on the chemistry of jute; Dr. B. N. Srivastava, Physics Department, University of Allahabad, distinguished for his work in thermodynamics; Dr. L. C. Verman, director of physical laboratories, Council for Scientific and Industrial Research, Delhi, distinguished for his work in applied physics.

\section{Geological Society Awards}

THE Council of the Geological Society announces the following awards :

Wollaston Medal to Dr. Joseph Burr Tyrrell, for his services to geological science in the Dominion of Canada, more particularly his pioneer work on the Barren Lands west of Hudson Bay and on the goldfields of Klondyke and Kirkland Lake.

Murchison Medal to Mr. Percy Evans, in recognition of his researches on the oilfields of Burma and Assam, and his work on the geological interpretation of gravitational surveys.

Lyell Medal to Dr. Stanley Smith, for his researches on Palæozoic corals, particularly their structure and relationships, and for his investigations into Lower Palæozoic and Carboniferous stratigraphy.

Bigsby Medal to Dr. George Hoole Mitchell, for his geological investigations in the Lake District and his work on the coalfields of Yorkshire and the Midlands.

Wollaston Fund to Dr. Austin William Woodland, for his work on the Cambrian rocks of Merionethshire and on the water supply of the Midlands and East Anglia.

Murchison Fund to Dr. Duncan Leitch, in recognition of his studies of the Carboniferous stratigraphy of Scotland and his investigations of the lamellibranch faunas of the Scottish coalfields.

A moiety of the Lyell Fund to Dr. Leslie Rowsell Moore, for his investigations of Upper Carboniferous faunas and floras of the Bristol, Somerset and South Wales coalfields; another moiety of the Lyell Fund to Mr. Claude William Wright, for his work on the faunas of the Cretaceous rocks of southern England and the Yorkshire and Lincolnshire wolds.

\section{Physical Society's Proposed Acoustics Group}

A menting of those interested in the formation of an Acoustics Group of the Physical Society will be held in the Jarvis Hall of the Royal Institute of British Architects, 66 Portland Place, London, W.1, at 3 p.m. on February 19. Mr. H. L. Kirke, head of the B.B.C. Research Department, will be in the chair, and Dr. Alex Wood will give an address on "The Contribution of Acoustical Science to Allied Studies". It is hoped to arrange an informal exhibition of recent acoustical apparatus. The agenda for the meeting will include a general discussion of the proposal to form such a group, the election of a chairman and officers, and the adoption of a set of rules. Those interested should send their names, indicating whether they will be able to attend the meeting, to the acting secretaries, Mr. A. T. Pickles and Mr. W. A. Allen, at the office of the Society, 1 Lowther Gardens, Prince Consort Road, London, S.W.7.

\section{Recenti Progressi in Medicina}

THE appearance of the first issue (dated October 1946) of Recenti Progressi in Medicina, a monthly review of international medical and surgical literature, published in Rome under the directorship of Giuseppe Lazzaro, supported by some twenty-eight collaborators, is an interesting development of post-war medical activity in Italy. This first issue, which owes much to the advice and experience of Prof. Giuseppe Bastianelli, to whom the editor pays a warm tribute, is mainly devoted to a review of recent progress in our knowledge of the various types of inflammation of the lungs. It deals not only with the types of pnoumonia caused by bacteria, but also with in. 
fluenzal pneumonia, coccidiomycosis, $Q$-fever and psittacosis. An especially long and detailed section, illustrated by X-ray photographs, deals with primary atypical pneumonia. Another article is devoted to the condition known to some as infiltration of Hegglen or pneumonia associated with a positive Wassermann reaction. Treatment of the pneumonias with penicillin and sulphonamides is the subject of another article, and there are abstracts from literature dealing with other aspects of the study of inflam. mation of the lungs. A short section records two immunological laboratory procedures. A bibliographical section consists entirely of the contents of the British Medical Journal during the months January to April 1946.

The next issue of this journal will be devoted to cecent progress in the treatment of disease with penicillin, and will contain articles by Sir Alexander Fleming and Sir Howard Florey, the translation of these two articles having been aided by the British Council. The editors offer a special word of thanks to the British Council and to the president of the Medical Section of American Relief in Italy for the help given to them in the publication of the journal. British and American sources predominate in the first issue. Future numbers will be awaited with interest. The journal should do much, not only to bring Italian medical men the latest information on a wide variety of subjects, but also to promote co-operation between them and medical men in other countries.

\section{Trees Used for Animal Fodder in India}

Indian Forest Leaflet No. 82 (Sylviculture) (Forest Research Institute, Dehra Dun. Pp. iv +17. 8 an.) discusses those trees the foliage of which is used for animal fodder in India. It is the third edition of a small publication written by M. V. Laurie, then sylviculturist at the Forest Research Institute, Dehra Dun, first issued in 1939. It was quickly sold out, as also was the second edition, the present being a revised third edition. India has been one of the countries the population of which has been much addicted to tree lopping, usually to provide forage for animals. With the appearance of the Animal Husbandry Wing of the Agricultural Research Council in India, a start was made in collecting information on the subject of fodder grasses and general fodder supplies. It was left to the Forest Research Institute at Dehra Dun to institute inquiries into the trees used for this purpose-and used very often to the detriment of the forests so maltreated. The list does not make any claim to scientific accuracy, but merely represents the consolidated opinions of forest officers throughout India of the relative popularity of different trees for lopping for fodder.

\section{British Council Scholarships, 1946-47}

For the current academic year, 248 graduates and others of like status from overseas have been awarded British Council scholarships, which enable them to take a wide range of post-graduate courses of study in British universities and similar institutions. The scholarships are normally for one year, but extensions are granted in suitable cases. In addition, the Council has helped to place many students who have come to Britain under the auspices of overseas authorities or privately. The Council has this year established a Students' Welfare Department to deal with the reception and non-academic welfare of scholarship holders, and to help them to gain a general knowledge of British life and institutions. To this end vacation courses, which enable those residing in London to visit the provinces and vice-versa, as well as term-time talks, discussions, shows of documentary films and other events are arranged. These facilities are available also to students sponsored by the Colonial Office, the Indian and Sudan Governments, and to other overseas students. Scholarship holders this year have come from some fifty Empire and foreign countries. The awards are for various subjects, including agriculture and agricultural sciences (6), engineering and mining (15), sciences and technology (50).

\section{Spectrochimica Acta}

AN international medium for the publication of research results in applied spectroscopy was launched in 1939, and published by Julius Springer in Berlin until 1944. This is being revived under the joint editorship of several spectroscopists, as before. The editorial board will consist of: Dr. A. Gatterer (Vatican Observatory), Mr. E. van Someren (London), Prof. R. Breckpot (Louvain), Dr. W. Gerlach (Munich), Dr. H. Kaiser (Jena) and Dr. L. W. Strock (Saratoga Springs). The first number of the third volume should appear early in 1947, and authors of papers on emission or absorption spectroscopy are invited to submit manuscripts, in English, French, German or Italian, to the nearest member of the editorial board. Publication should be fairly prompt, by current standards. As in most scientific publications, authors are urged to be concise; but the paper supplies are sufficient to allow each author 75 reprints. The printing will be undertaken by the printers in the Vatican City, who are accustomed to dealing with a variety of languages. Authors in Great Britain should communicate with Mr. E. van Someren, 20 Churchfields, Broxbourne, Herts.

\section{Announcements}

The Medical Research Council has appointed Dr. S. T. Cowan (formerly of the University of Manchester) to succeed Dr. R. St. John Brooks as director of the National Collection of Type Cultures of Microorganisms. The Collection continues to be housed at the Elstree establishment of the Lister Institute of Preventive Medicine, but will be moved to the Central Public Health Laboratory at Colindale as soon as accommodation there is available.

Mr. J. B. BenNetT has been appointed to succeed the late Mr. W. Barnicot as secretary of Rothamsted Experimental Station.

IN accordance with its usual practice, Trinity College, Cambridge, announces the offer of a research studentship open to graduates of other universities who propose to go to Cambridge in October next as candidates for the degree of Ph.D. The value of the studentship may be as much as $£ 300$ a year. Candidates must not have reached the age of twenty-six before May 1 (length of war service can be added). The College also offers, as usual, exhibitions of the value of $£ 40$ to students of Dominion and Colonial universities who wish to go to Cambridge next October as candidates for the degree of B.A., M.Litt., M.Sc., or Ph.D. A candidate for a studentship or exhibition should apply through the principal authority of his university, and his application must reach the Senior Tutor, Trinity College, Cambridge (from whom further particulars may be obtained), by May 1. 